This manuscript is contextually identical with the following published paper:

B-Béres V., Tóthmérész B., Bácsi I., Borics G., Abonyi A., Tapolczai K., Rimet F., Bouchez A., Várbíró G., Török P. (2019): Autumn drought drives functional diversity of benthic diatom assemblages of continental

streams. Advances in Water Resources 126: 129-136.

The original published PDF available in this website:

https://doi.org/10.1016/i.advwatres.2019.02.010

\title{
Autumn drought drives functional diversity of benthic diatom assemblages of continental intermittent streams
}

\author{
Viktória B-Béres ${ }^{\mathrm{a}, \mathrm{b}}$, Béla Tóthmérész ${ }^{\mathrm{c}}$, István Bácsi ${ }^{\mathrm{d}}$, Gábor Borics ${ }^{\mathrm{b}, \mathrm{e}}$, András Abonyi ${ }^{\mathrm{f}}$, \\ Kálmán Tapolczai ${ }^{\mathrm{g}, \mathrm{h}}$, Frederic Rimet ${ }^{\mathrm{i}}$, Ágnes Bouchez ${ }^{\mathrm{i}}$, Gábor Várbíró ${ }^{\mathrm{b}, \mathrm{e}}$, Péter Török ${ }^{\mathrm{a}, *}$ \\ ${ }^{a}$ MTA-DE Lendület Functional and Restoration Ecology Research Group, H-4032 Debrecen, Egyetem tér 1, Hungary \\ ${ }^{\mathrm{b}}$ MTA Centre for Ecological Research, GINOP Sustainable Ecosystems Group, H-8237 Tihany, Klebelsberg Kuno u. 3, Hungary \\ c University of Debrecen, Department of Ecology, H-4032 Debrecen, Egyetem tér 1, Hungary \\ ${ }^{d}$ University of Debrecen, Department of Hydrobiology, H-4032 Debrecen, Egyetem tér 1, Hungary \\ ${ }^{\mathrm{e}}$ MTA Centre for Ecological Research, Danube Research Institute, Department of Tisza Research, H-4026 Debrecen, Bem tér 1, Hungary \\ ${ }_{\mathrm{f}}^{\mathrm{f}}$ MTA Centre for Ecological Research, Institute of Ecology and Botany, H-2163 Vácrátót, Alkotmány u. 2-4, Hungary \\ ${ }^{\mathrm{g}}$ Department of Limnology, University of Pannonia, H-8200 Veszprém, Egyetem u. 10, Hungary \\ ${ }^{\mathrm{h}}$ Hungarian Academy of Sciences, Premium Postdoctoral Research Program, H-1051 Budapest, Nádor u. 7, Hungary \\ i INRA, UMR CARRTEL, FR-74203 Thonon, 75bis av. de Corzent, France
}

article in fo

\section{Keywords:}

Continental region

Diatoms

Ecosystem functioning

Intermittent streams

\begin{abstract}
a b s $\quad$ t $\mathbf{r}$ a $c$ c $\mathbf{t}$
Climate change is predicted to increase drought occurrence and severity in small continental watercourses. Here, we studied the structure and the functional diversity of benthic diatom assemblages in lowland intermittent and permanent watercourses of the Carpathian Basin. We assumed that the community structure of intermittent and permanent watercourses would be markedly diff erent, and the functional diversity in both would be strongly influenced by autumn drought. We found that intermittent streams were primarily characterized by small-sized generalists and aerophilic taxa, while permanent watercourses were inhabited by large-sized planktic or fast moving groups. The functional richness was significantly lower in intermittent than in permanent streams. This decrease in the functional richness of benthic algal communities may negatively aff ect the functioning of lotic algal communities. We conclude that diatom assemblages in lowland intermittent watercourses are sensitive indicators of changes in ecosystem properties, and should be considered in appropriate evaluation and management of extreme climatic events on aquatic ecosystems.
\end{abstract}

\section{Introduction}

Terrestrial and aquatic ecosystems are threatened by the increasing frequency and/or intensity of extreme climate events worldwide (Meehl et al., 2000; Tölle et al., 2017). Extreme weather events, such as droughts and floods, are strongly related to warmer climatic conditions and may become more frequent and intense (IPCC, 2014). Due to the methodological uncertainties in data acquisition and the resulting inconsistencies in the available data, there is currently limited evidence for increased global drought; however, dryness could become more common at the local scale (IPCC, 2014). Droughts are complex phenomena, which are generally considered to be disturbances with strong negative influence on ecosystem function (Rosett et al., 2017). However, the impact of a disturbance is system dependent (Borics et al., 2013), and usually only extreme drought events have a strong impact on the composition of ecological communities (Acuna et al., 2017).

In the past $30-50$ years, remarkable shifts in the climate zones/subzones were observed globally (Belda et al., 2014). Semi-arid regions have extended into continental climate regions (Belda et al., 2014). Furthermore, increases in the land surface area of the continental regions have been observed in parallel with an area decrease of boreal regions (Belda et al., 2014). These changes are probably related to the more pronounced climate change during the 20th century (Belda et al., 2014). The Carpathian Basin belongs to the continental region. Here, the mean annual temperature increased by $\sim 1{ }^{\circ} \mathrm{C}$ during the 20th century (Bartholy et al., 2014), while precipitation events became less frequent (Bartholy and Pongrácz, 2005). These trends became more prevalent in the first period of the 21st century (Bartholy et al., 2014).

\footnotetext{
* Corresponding author.

E-mail addresses: borics.gabor@okologia.mta.hu (G. Borics), tapolczai.kalman@almos.uni-pannon.hu (K. Tapolczai), frederic.rimet@inra.fr (F. Rimet), agnes.bouchez@inra.fr (Á. Bouchez), varbiro.gabor@okologia.mta.hu (G. Várbíró), molinia@gmail.com (P. Török).
} 
In this area of Europe, the most arid season has shifted from winter to late summer (Bartholy et al., 2014). The climatic changes of the last decade led to changes in the water regime of lowland streams in this region, inducing the drying up of these formerly permanent watercourses in the late summer period. The diff erence between drought regulated permanent streams and naturally occurring temporary streams in the Carpathian Basin has become less distinct. The hotter and drier summers predicted in climate change scenarios for this region may result in typological changes of watercourses. Similar to the Mediterranean and other arid regions, temporary streams may become natural in the Carpathian Basin.

Temporary streams are special lotic ecosystems which cease to flow for part of the year (Acuna et al., 2017; Skoulikidis et al., 2017). Depending on the length of the drying up phase, these ecosystems can be classified as intermittent (presence of water for longer than 8 months), ephemeral (less than 8 months) or episodic (water is in the river bed only after periods of intense precipitation) (Skoulikidis et al., 2017). Temporary streams are widespread in semi-arid to Mediterranean regions (Stubbington et al., 2018), where they contribute to landscapelevel biodiversity and provide multiple ecosystem services, such as storage of nutrients, accessible sand mining, gravel and fertile substrate for agriculture, refuge for aquatic organisms, and corridors for terrestrial organisms (Acuna et al., 2014,2017; Steward et al., 2012; Stubbington et al., 2017, 2018). Despite their high ecological and economical importance, temporary streams are among the most vulnerable ecosystems on Earth. They are threatened by anthropogenic impacts and natural hazards such as inappropriate landscape and waste water management, over-abstractions or climatic extremities (Skoulikidis et al., 2017).

Given the predictions for increased extreme climatic events in continental regions (Babka et al., 2018; IPCC, 2014), for eff ective biodiversity conservation of lowland streams, it is crucial to understand the biodiversity dynamics induced by severe droughts. At local scales, temporary streams are considered primarily as "low-biodiversity ecosystems" both during the flowing phase (Stubbington et al., 2017; Tornes and Ruhi, 2013) and the drying period (Acuna et al., 2015; Rothrock and GarciaPichel, 2005). Globally, however, these watercourses may be more diverse than perennial ones (Stubbington et al., 2017). While perennial streams are mainly dominated by lotic taxa, lentic and terrestrial species can be also characteristic elements of communities in temporary watercourses (Stubbington et al., 2017).

Among the various benthic groups inhabiting streams, benthic diatoms are one of the best model organisms for studying drought eff ects on the biota of lotic environments. Recent studies primarily focused on the community structure of diatoms in temporary and perennial streams in Mediterranean regions, including both lowland and mountainous areas (Barthès et al., 2015; Falasco et al., 2016; Novais et al., 2014; Piano et al., 2017; Tornes and Ruhi, 2013). Significant diff erences in community compositions have repeatedly been found between stream types (Falasco et al., 2016; Novais et al., 2014; Piano et al., 2017; Tornes and Ruhi, 2013). Although water scarcity as well as the presence of temporary streams is natural in the Mediterranean regions, diatom communities of these watercourses are dominated by generalists like small sized taxa, including pioneers or drought indicator species. These groups are known as indicators of physically disturbed environments (B-Béres et al., 2014, 2016; Berthon et al., 2011; Rimet and Bouchez, 2012; StengerKovács et al., 2013), and have the potential to indicate ecological quality in intermittent streams, even during the dry-phase (Stubbington et al., 2019). In contrast, specialists and endangered taxa are characteristic of perennial streams (Falasco et al., 2016; Novais et al., 2014; Piano et al., 2017; Tornes and Ruhi, 2013).

Studies of diatom communities of temporary streams are more commonly focused on Mediterranean regions, but are limited for continental Europe. This is probably due to the natural occurrence of temporary streams in semi-arid and Mediterranean regions, where the influence of flow cessation or of the water disappearance on communities are well-documented (Acuna et al., 2017). In contrast, recurring drying up of lowland streams and the perennial-intermittent typological shifts are new phenomena in continental regions, occurring only in the last decades. There are no well-developed management and stream/ecosystem protection strategies based on accurate studies. Lowland watercourses are typically not in a good ecological status in continental regions, especially in the Carpathian Basin (web 1). Due to the intense agricultural activities in the region, the nutrient load of these streams is high (web 1). There is no information on how the ecological quality of these watercourses would change under the stress caused by recurring drought. This information would be necessary for the eff ective maintenance and protection of these valuable lowland ecosystems.

Here, we tested whether the drying up of lowland streams could induce significant changes in the functional diversity of benthic diatom communities, compared with perennial watercourses, in the Carpathian Basin. We hypothesised the following: (i) The community structure in intermittent and permanent streams diff ers: Small sized taxa, and/or pioneers and/or drought indicator (e.g. aerophilic) groups would be more characteristic in intermittent streams, while motile, medium to large sized diatoms characteristic to lotic ecosystems would dominate in the permanent watercourses. (ii) Functional diversity is strongly influenced by autumn drought and intermittent watercourses are expected to have lower diversity than permanent watercourses.

\section{Materials and methods}

\subsection{Sampling area, sampling setup and measurements}

In the Carpathian Basin the growing season (from April to September) experienced increasing frequency of drought events during the last decade, especially in the eastern part of the Basin. These dry episodes induced the recurring drying up of many formerly permanent watercourses and resulted in a yearly pattern of alternating dry and flowing phases. Altogether 34 diatom samples were collected from small sized, lowland perennial watercourses and intermittent streams, during the spring flowing phase in the Carpathian Basin, between 2008 and 2015 (Fig. 1, Appendix 1). According to the 2nd River Basin Management Plan (web1), the studied streams can be categorised as calcareous, lowland watercourses, with coarse or medium sized sediment, in small or medium sized catchments (R-E2 GIG-type; EC 915). Due to the intensive agricultural activity in the region, the ecological status of all streams was moderate (web1). Since the watercourses were dried up in late summer or early autumn of the previous year of sampling (absence of water in the river bed was less than 4 months; usually 1-2 months) they were referred to as intermittent streams. Eight physical and chemical parameters were measured in all sampling sites. Water temperature $\left(\mathrm{T}-{ }^{\circ} \mathrm{C}\right)$ and conductivity $\left(\mathrm{COND}-\mu \mathrm{S} \mathrm{cm}{ }^{-1}\right.$ ), were measured directly in the field with a portable-multi-parameter digital meter (Multi 350i-WTW, Germany). The water samples were kept at $4{ }^{\circ} \mathrm{C}$ in a cooler bag during transportation to the laboratory for further analyses. Nutrient concentrations $\left(\mathrm{NO}_{3}{ }^{-}, \mathrm{NO}_{2}{ }^{-}, \mathrm{NH}_{4}{ }^{+}\right.$and $\left.\mathrm{PO}_{4}{ }^{3-}\right)$ and chloride $\left(\mathrm{Cl}^{-}\right)$were determined spectrophotometrically according to ISO 15923-1 (2013) standard. Respirometric analysis was used to determine the Biological Oxygen Demand (BOD) according to MSZ EN 1899-1 (2000) and MSZ ISO 6060 (1991) standards.

\subsection{Diatom sample collection and preparation}

All sampling and preservation were performed according to the European guideline (EN 13946). Diatom samples were collected from all streams, during the flowing phase, from emergent macrophytes growing in the free-flowing parts of the riverbeds. Diatom valves were prepared by the hot hydrogen-peroxide method (EN 13946). Naphrax resin was used for embedding. According to the European guideline (EN 14407), at least 400 diatom valves were identified and counted using a Leica 


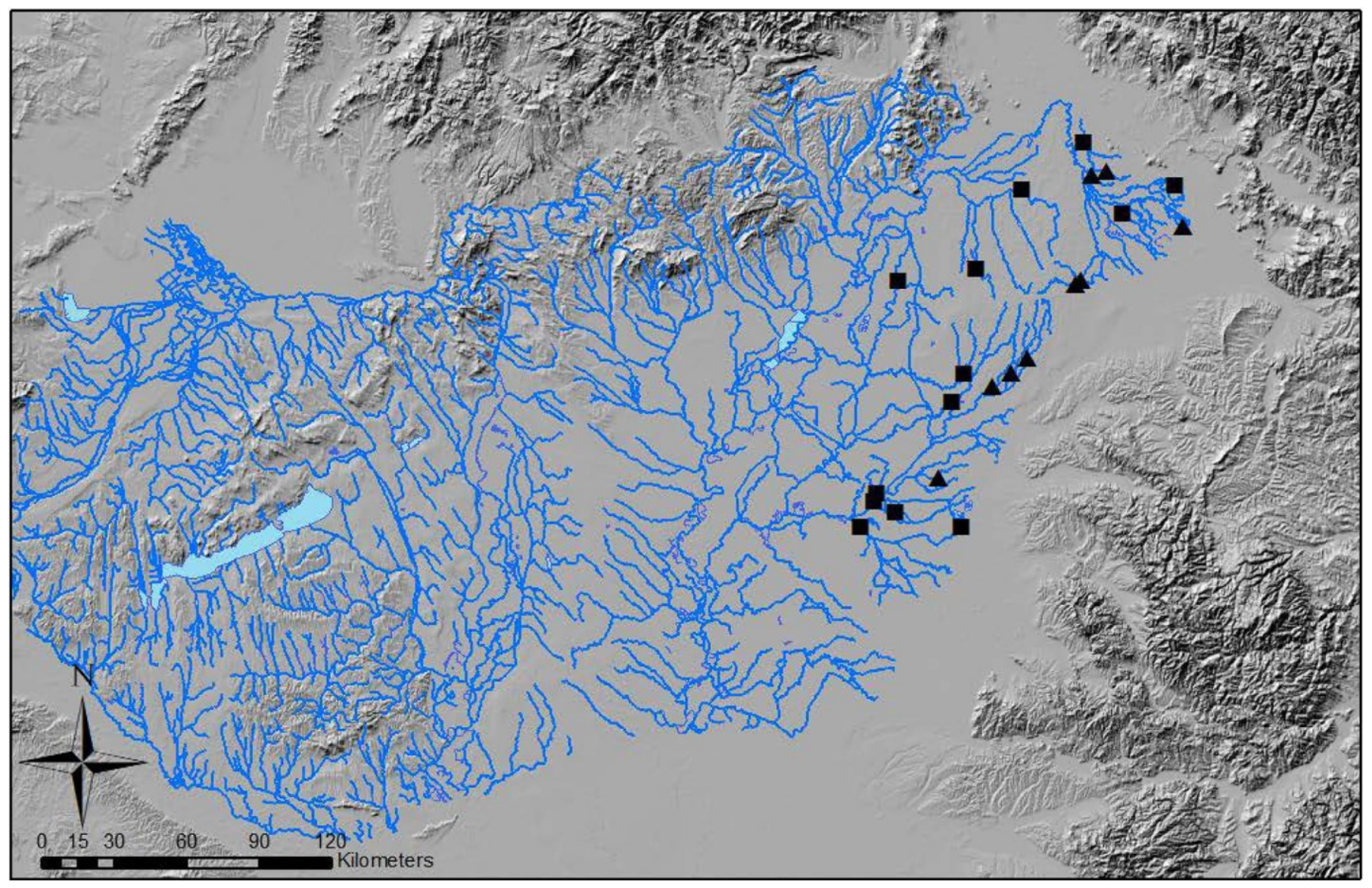

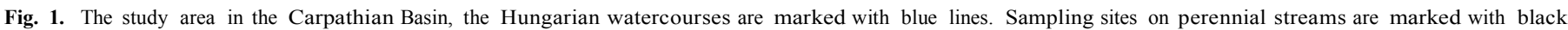
squares. Sampling sites on intermittent streams are marked with black triangles.

DMRB microscope with 1000-1600-fold magnification. The identification of diatom taxa was carried out using up-to-date literature (Krammer and Lange-Bertalot, 1997a,b; Krammer and Lange-Bertalot, 2004a,b; Potapova and Hamilton, 2007; Stenger-Kovács and Lengyel, 2015).

\subsection{Data processing and analyses}

A total of 212 diatom taxa were identified in the samples (208 taxa to species level and 4 to genus level). Diatom taxa were classified into guilds (planktic, low profile, high profile and motile - Table 1; Passy, 2007; Rimet and Bouchez, 2012). A database containing average cell size value of taxa was used to classify diatoms into five cell size classes (Table 1; Rimet and Bouchez, 2012). This database also contains information about the average length and width of diatoms' valves. These data were used to calculate the LW ratio (length/width; Table 1). The taxa were classified into LW ratio groups according to StengerKovács et al. (2018). Taxa were referred to as pioneers and mobile according to the above mentioned database (Rimet and Bouchez, 2012). Diatom taxa were classified into halophile or non-halophile groups according to van Dam et al. (1994; Table 1). Habitat descriptions found in Krammer and Lange-Bertalot (1997a, 1997b), Krammer and LangeBertalot (2004a, 2004b), Hofmann et al. (2011) were used to ascertain the moisture requirement of taxa. Based on these descriptions, aerophilous and non-aerophilous groups were distinguished. Taxa were referred to as invaders according to Kastovsky et al. (2010).

For testing significant diff erences in physical and chemical parameters between perennial and intermittent stream sites, we applied the Kruskal-Wallis and the Wilcoxon rank sum tests using the $\mathrm{R}$ package 'vegan' (ter Braak and Smilauer, 2002). To analyse the relationship between environmental factors and traits, we used redundancy
Table 1

Applied morphological and functional traits and their categories.

\begin{tabular}{ll}
\hline Type of traits & Trait categories \\
\hline Guilds & low profile \\
& high profile \\
& motile \\
planktic \\
Cell size & S1: $5-99 \mu \mathrm{m}^{3}$ \\
& S2: $100-299 \mu \mathrm{m}^{3}$ \\
& S3: $300-599 \mu \mathrm{m}^{3}$ \\
& S4: $600-1499 \mu \mathrm{m}^{3}$ \\
& S5: $\geq 1500 \mu \mathrm{m}^{3}$ \\
Length/Width & LW1: $<2$ \\
& LW2:2-4 \\
& LW3: $4-6$ \\
& LW4: $6-12$ \\
& LW5: $12-20$ \\
Halotolerance & LW6: $>20$ \\
Mobility & halophile \\
Moisture & non-halophile \\
Spreading and colonisation & mobile \\
& aerophile \\
& non-aerophile \\
& invaders \\
& pioneers \\
\hline
\end{tabular}

analyses (RDA), applying CANOCO 5.0 software package (ter Braak and Smilauer, 2002), where environmental factors were added by the method of weighted averaging (ter Braak and Smilauer, 2002). We used Monte Carlo permutation tests (default 499 permutations) to decide 
whether the detected pattern was significantly diff erent from random. To compare the functional diversity characteristics between intermittent and perennial streams, we used one-way ANOVA (ter Braak and Smilauer, 2002). The fixed factor was stream type and the dependent variables were the various functional diversity metrics (FRich, FEve, FDiv explained later in the text) and Berger-Parker diversity.

Complementary aspects of species distributions in niche space can be measured by functional diversity components. Thus, we calculated functional richness (FRich), functional evenness (FEve) and functional divergence (FDiv) (Mason et al., 2005). According to Mason et al. (2005) these components indicate (i) "the amount of niche space filled by species" (FRich); (ii) "the evenness of abundance distribution in filled niche space" (FEve); and (iii) "the degree to which abundance distribution in niche space maximises divergence in functional characters within the community" (FDiv) (Mason et al., 2005). The 'FD' R package was used for calculation of these functional diversity metrics (Laliberté and Legendre, 2010; Laliberté et al., 2014).

The Berger-Parker index, $d$, is a simple metric for measuring dominance (Berger and Parker, 1970; May 1975). It has been defined as the proportional abundance of the most abundant species in the assemblage:

$\mathrm{d}=\mathrm{N}_{\max } / \mathrm{N}$

where $\mathrm{N}_{\max }=$ the number of individuals in the most abundant species or trait; $\mathrm{N}=$ the observed number of the species in the sample. The increase in the value of the Berger-Parker index coincides with a decrease in diversity and an increase in dominance. We calculated the BergerParker diversity index using the PAST software package (version 2.11; Hammer et al., 2001).

\section{Results}

\subsection{Relationship between diatom traits and environmental factors}

RDA analysis indicated diff erences between perennial and intermittent streams based on the functional trait composition of benthic diatoms (Fig. 2). While environmental parameters did not diff er significantly between perennial and intermittent streams (Table 2), they explained $25.99 \%$ variance in the functional community structuring of benthic diatoms. The eigenvalues for the first and second axes were 0.13 and 0.07 . The environmental variables that highly correlated with axis 1 were $\operatorname{BOD}(0.57)$ and nitrate $(0.28)$, while temperature $(0.41)$ and orthophosphate $(0.26)$ were the most important variables to axis 2 .

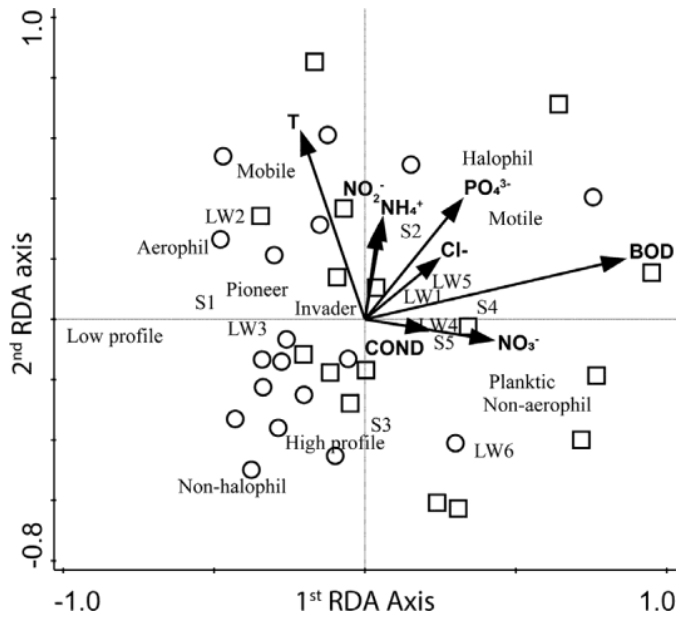

Fig. 2. Relation of traits and the environmental variables displayed by RDA based on trait abundances. The explained variations were $16.7 \%$ and $5.6 \%$ for the first and second axes respectively. Intermittent streams are marked with circles. Perennial watercourses are marked with squares.

The Monte Carlo permutation test indicated a significant diff erence from random for the final model (Number of permutation $s=499 ; p=0.02$ for all canonical axes).

Functional characteristics of diatom communities of intermittent streams were negatively correlated with all environmental factors. Small sized, pioneer taxa and aerophilic taxa characterized the diatom communities of these streams. In contrast, diatom communities of perennial streams were characterized either by motile taxa with a large LW ratio, or by planktic taxa. Permanent streams were also preferred by halophilous and large sized taxa (Fig. 2).

\subsection{Differences in functional diversity}

The functional richness was significantly lower in the intermittent streams than in perennial ones (Fig. $3 \mathrm{a} ; p<0.005$ ). In contrast, there were no significant diff erences between watercourses in either functional evenness or functional divergence (Fig. 3b,c; $p>0.1$ ). The BergerParker diversity was significantly higher in the intermittent streams than in the perennial watercourses (Fig. $3 \mathrm{~d} ; p<0.05$ ). There was also a strong

Table 2

Summary of the data set for the six tested chemical and physical parameters in intermittent and perennial lowland streams, and the results of the Wilcoxon rank sum test: biological oxygen demand (BOD - mg $\mathrm{L}^{-1}$ ), water temperature $\left(\mathrm{T},{ }^{\circ} \mathrm{C}\right)$, ammonium $\left(\mathrm{NH}_{4}{ }^{+}-\mathrm{mg} \mathrm{L^{-1 }}\right)$, nitrate $\left(\mathrm{NO}_{3}{ }^{-}-\mathrm{mg} \mathrm{L^{-1 }}\right)$, nitrite $\left(\mathrm{NO}_{2}{ }^{-}-\mathrm{mg} \mathrm{L}^{-1}\right)$, soluble reactive phosphorus $\left(\mathrm{PO}_{4}{ }^{3-} \mu \mathrm{g} \mathrm{L}^{-1}\right)$, chloride $\left(\mathrm{Cl}^{-}-\mathrm{mg} \mathrm{L} \mathrm{L}^{-1}\right)$, and conductivity $\left(\mathrm{COND}-\mathrm{mg} \mathrm{L}^{-1}\right)$.

\begin{tabular}{|c|c|c|c|c|c|c|c|c|}
\hline & & average & SD & median & minimum & maximum & $\mathrm{W}$ & p-value \\
\hline \multirow[t]{2}{*}{ BOD $\left(\mathrm{mg} \mathrm{L}^{-1}\right)$} & Intermittent & 2.73 & 1.59 & 2.30 & 6.90 & 1.39 & 198.5 & 0.06226 \\
\hline & Perennial & 3.59 & 1.93 & 2.85 & 8.10 & 2.00 & & \\
\hline \multirow[t]{2}{*}{$\mathbf{T}\left({ }^{\circ} \mathrm{C}\right)$} & Intermittent & 16.22 & 3.64 & 16.95 & 23.10 & 7.60 & 117.5 & 0.3965 \\
\hline & Perennial & 14.09 & 9.04 & 15.40 & 27.50 & 1.80 & & \\
\hline \multirow{2}{*}{$\mathrm{NH}_{4}{ }^{+}\left(\mathrm{mg} \mathrm{L}^{-1}\right)$} & Intermittent & 2.14 & 6.59 & 0.09 & 27.20 & 0.03 & 139.5 & 0.8899 \\
\hline & Perennial & 0.15 & 0.15 & 0.09 & 0.53 & 0.03 & & \\
\hline \multirow[t]{2}{*}{$\mathrm{NO}_{3}{ }^{-}\left(\mathrm{mg} \mathrm{L} \mathrm{L}^{-1}\right)$} & Intermittent & 1.33 & 1.09 & 0.85 & 4.00 & 0.40 & 194 & 0.08673 \\
\hline & Perennial & 4.78 & 6.59 & 1.85 & 23.50 & 0.50 & & \\
\hline \multirow[t]{2}{*}{$\mathrm{NO}_{2}{ }^{-}\left(\mathrm{mg} \mathrm{L} \mathrm{L}^{-1}\right)$} & Intermittent & 0.06 & 0.04 & 0.06 & 0.15 & 0.01 & 156.5 & 0.6772 \\
\hline & Perennial & 0.08 & 0.08 & 0.05 & 0.24 & 0.01 & & \\
\hline \multirow[t]{2}{*}{$\mathrm{PO}_{4}{ }^{3-}\left(\mu \mathrm{g} \mathrm{L}^{-1}\right)$} & Intermittent & 830.02 & 1023.04 & 473.00 & 4190.00 & 88.70 & 156 & 0.6953 \\
\hline & Perennial & 941.22 & 988.42 & 608.00 & 3420.00 & 27.80 & & \\
\hline \multirow[t]{2}{*}{$\mathrm{Cl}^{-}\left(\mathrm{mg} \mathrm{L} \mathrm{L}^{-1}\right)$} & Intermittent & 35.62 & 24.48 & 26 & 7 & 95 & 164 & 0.5009 \\
\hline & Perennial & 48.31 & 37.88 & 36 & 9 & 142 & & \\
\hline \multirow[t]{2}{*}{$\operatorname{COND}\left(\mu \mathrm{S} \mathbf{c m}^{-1}\right)$} & Intermittent & 672 & 236 & 700 & 159 & 1120 & 149 & 0.8782 \\
\hline & Perennial & 730 & 445 & 724 & 110 & 1450 & & \\
\hline
\end{tabular}



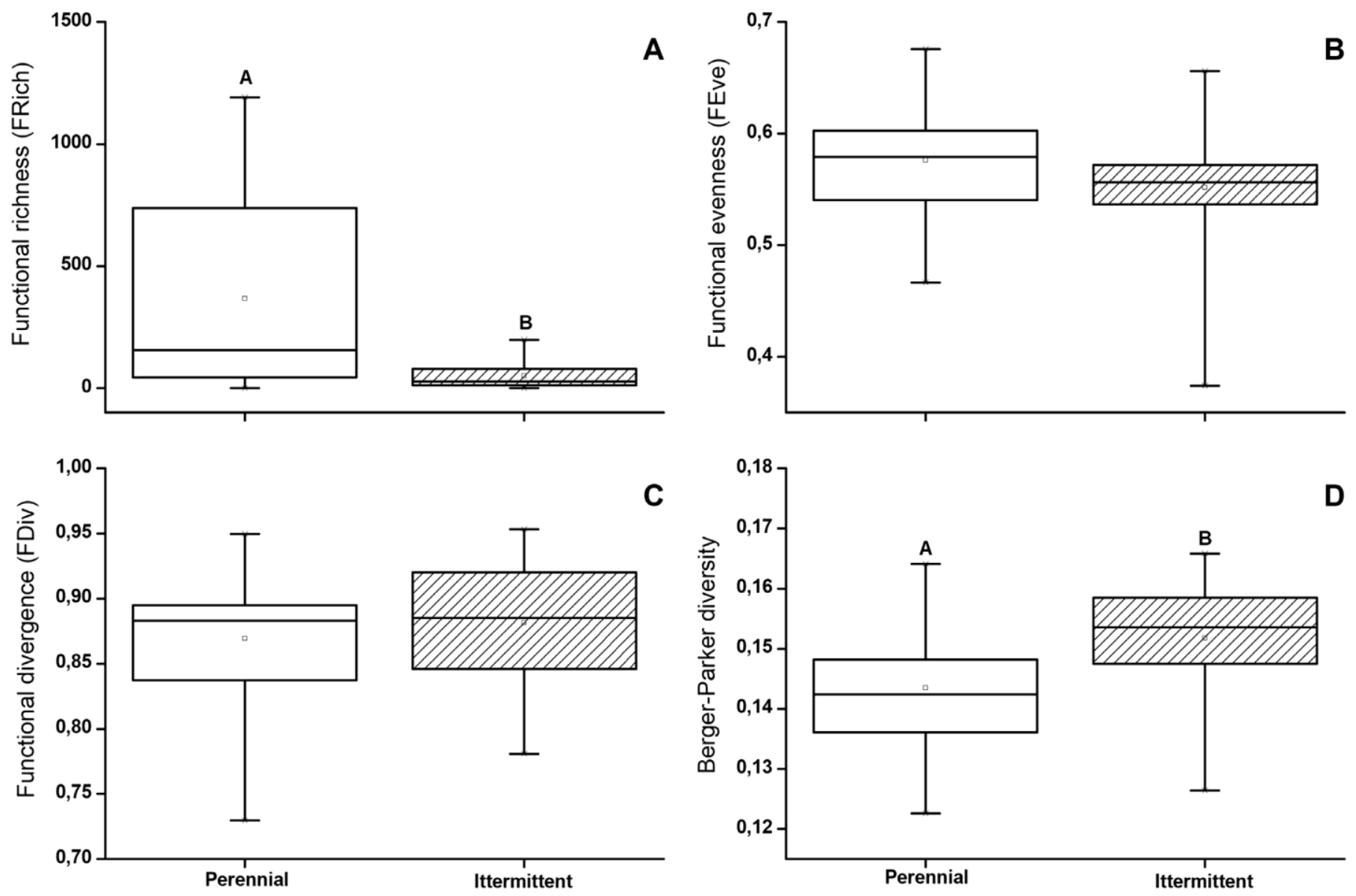

Stream type

Fig. 3. Functional richness (A), functional evenness (B), functional divergence (C) and the Berger-Parker diversity (D) in the perennial and intermittent streams. Results of Kruskal-Wallis and ANOVA tests were: $\mathrm{KW}-\mathrm{H}=9.742, p=0.0018$ and $\mathrm{F}=11.8598, p=0.0015$ in the case of functional richness; $\mathrm{KW}-\mathrm{H}=2.2655, p=0.1323$ and $\mathrm{F}=1.6562, p=0.2068$ in the case of functional evenness; $\mathrm{KW}-\mathrm{H}=0.2734, p=0.6011, \mathrm{~F}=0.4532, p=0.5054$ in the case of functional divergence and $\mathrm{KW}$ $\mathrm{H}=7.0868, p=0.0078$ and $\mathrm{F}=5.8021, p=0.0216$ in the case of Berger-Parker diversity.

positive correlation between Berger-Parker trait diversity and the pioneer traits (Fig. $4 ; p<0.05$ ).

\section{Discussion}

\subsection{Trait compositions differ significantly in intermittent and permanent streams}

In the Carpathian Basin, there is a clearly visible shift in water supply of lowland watercourses, especially during the vegetation period (from April to September), inducing the recurring drying up of some of these formerly permanent streams. Since this shift began only very recently, water scarcity should be considered as a physical disturbance to these ecosystems. We hypothesised that the community structure in the disturbed intermittent and the permanent streams would be markedly diff erent; and that we could identify traits indicating the drying up of lowland watercourses. Our results confirmed this hypothesis. Similar to previous findings (Falasco et al., 2016) aerophilous taxa were strong indicators of drought. These taxa are able to survive the drying up of the streams and to rapidly colonise habitats after the return of water flow. Similarly to invertebrates (Datry et al., 2014) and to the Mediterranean diatom communities (Piano et al., 2017), generalists, including pioneers and small low profile taxa, were also characteristic of the studied intermittent streams. These taxa can tolerate physical disturbances and they are able to spread rapidly (Berthon et al., 2011; B-Béres et al.,
2014, 2016). Conversely, Falasco et al. (2016) found positive correlation between low profile guild diversity, including pioneer species, and upstream watercourse sections characterised by permanent flow conditions, in the Ligurian Apennines and the Alps. The authors also found lower nutrient content in these perennial streams than in the intermittent streams, while we observed the opposite phenomenon: intermittent stream diversity correlated negatively to environmental factors, such as increased nutrient content, in our study. To understand these seeming contradictions, two diff erent environmental parameters must be considered: nutrient content and drought intensity. Upstream watercourse sections in mountains are usually dominated by low profile and/or pioneer taxa (Rimet et al., 2007). In addition, their nutrient contents are usually lower than in downstream sections (Abonyi et al., 2012). We studied only lowland streams, which were all characterised by moderate ecological status (web 1). Environmental parameters did not diff er significantly between intermittent and perennial streams in our study. With some exceptions, the nutrient load (especially the nitrate content and the amount of the biodegradable organic material indicated by BOD) was usually lower in intermittent streams than in perennial watercourses. Thus, it appeared that not only the drought periods, but also the lower nutrient concentrations, determined the dominance of low profile and pioneer taxa in benthic algal assemblages in the studied intermittent streams.

As it has been already noted, there were no significant diff erences in the environmental parameters between perennial and intermittent 


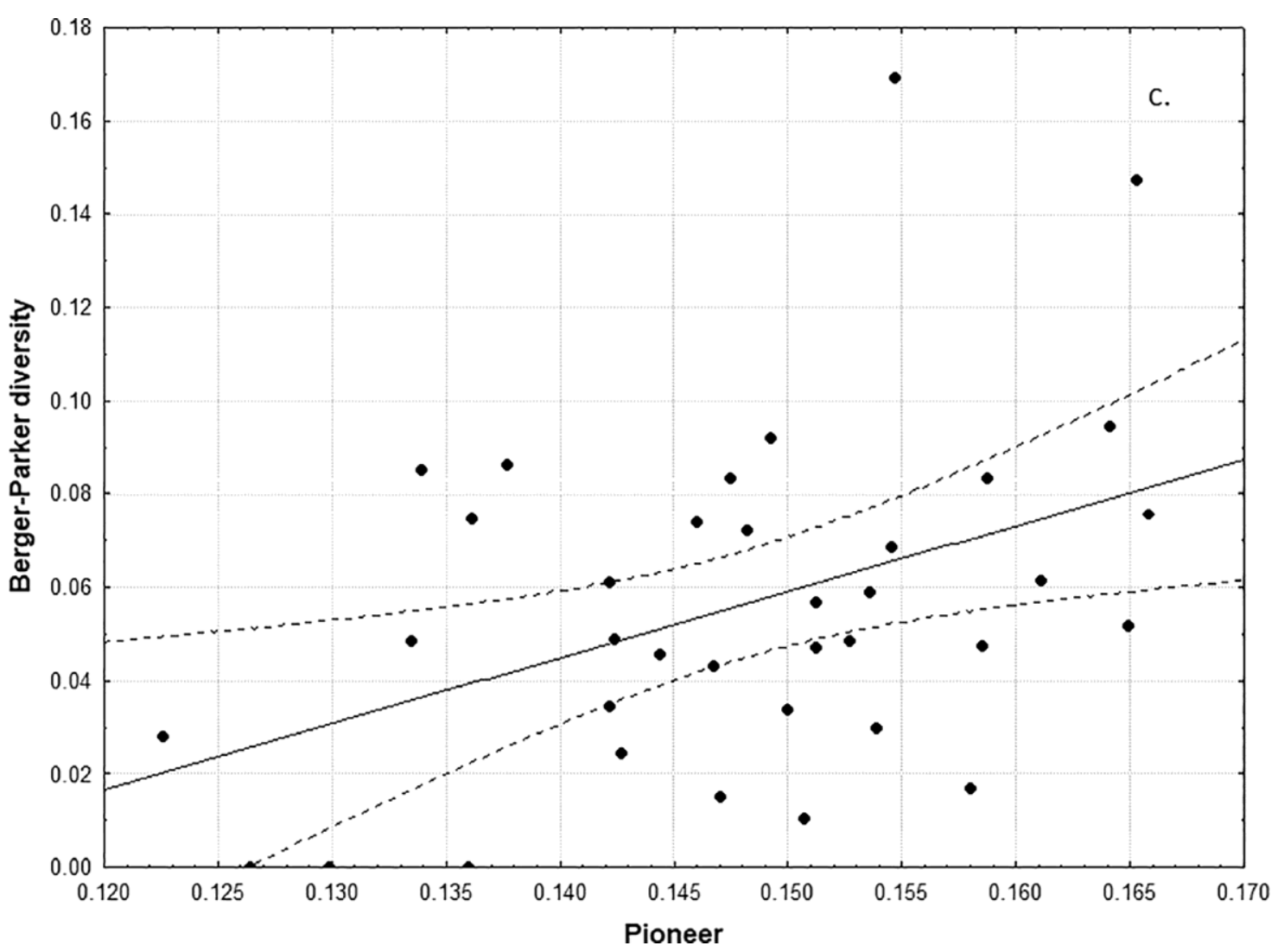

Fig. 4. Linear regression between Berger-Parker diversity and relative abundance of pioneers where $p=0.0103, r^{2}=0.1784(\mathrm{c})$.

streams. However, the functional characteristics of diatom communities of the permanent watercourses correlated positively to nutrients, such as nitrate, and to biodegradable organic materials. In accordance with previous findings (Tornes and Ruhi, 2013), the perennial watercourses of our study were characterised by specialist diatom species showing high length/width ratios, large size and motility. The motile taxa have an advantage in resource acquisition under increased nutrient levels (Berthon et al., 2011; B-Béres et al., 2014,2017; Passy and Larson 2011). We also observed that halophilic taxa were more abundant in perennial rivers, likely due to increasing resource availability, as observed in the River Wipper (Ziemann et al., 2001) and in lowland small streams (Kókai et al., 2015). Finally, the presence of planktic taxa was another characteristic of diatom assemblages in our perennial streams, which may indicate a water velocity reduction (B-Béres et al., 2017; Rimet and Bouchez, 2012). This characteristic is also a typical example of source-sink dynamic (Leibold and Chase, 2018), and can be frequently observed in small streams with lakes or reservoirs in their upstream sections (Bolgovics et al., 2015; 2017).

\subsection{Reduced functionality characterises lowland intermittent streams in temperate regions}

Intermittent watercourses are usually considered to be "low biodiversity ecosystems" at the local scale (Stubbington et al., 2017), and therefore we expected lower diversity in these streams than in permanent ones. Our results confirmed this hypothesis. The observed low functional richness, together with the high Berger-Parker diversity of traits, indicated the strong negative impact of drought on biodiversity in these lowland intermittent watercourses.

Disturbed environments can be characterised by the dominance of pioneers (B-Béres et al., 2014, 2016; Stenger-Kovács et al., 2013) and by reduced functionality. This reduced functionality coincides with reduced productivity (Mason et al., 2005). The lowland intermittent watercourses in the Carpathian Basin are subject to water scarcity induced disturbances, making them more vulnerable to change than perennial watercourses (Mason et al., 2005). Highly disturbed systems can be particularly sensitive to invaders (Cooper et al., 2013). However, it can be challenging to define diatoms as invaders in freshwater ecosystems. The GISD (http://www.iucngisd.org/gisd/) identifies only one diatom species as invader in these ecosystems, although Kastovsky et al. (2010) published a more detailed database focusing on freshwaters in the Czech Republic. In our study, only one motile halophilic taxon was specified as an 'invader' (Navicula schroeteri), according to Kastovsky et al. (2010), and occurred in only one perennial stream. Non native invaders were not present in intermittent streams.

The functional richness of communities was significantly lower in intermittent streams than in perennial ones, clearly indicating the negative eff ect of water scarcity on community composition. In contrast, functional evenness and functional divergence values did not diff er in temporary and permanent watercourses. Our results suggested that the autumn drought was a strong stressor for diatom communities, independent of stream type. These findings are consistent with the results of a previous study in the Carpathian Basin, where decreasing evenness was found in small permanent watercourses during the autumn drought (Kókai et al., 2015).

\section{Conclusions}

Our findings highlighted the vulnerability of lowland intermittent streams in the Carpathian Basin, where the recurring drying up of these watercourses was due to water scarcity during the vegetation period. We revealed significant diff erences in trait compositions of these lotic 
ecosystems; the presence of small sized aerophilous and/or low profile taxa, including pioneers, indicated the drying up of the watercourses. In contrast, motility and large sized taxa, together with halophiles, characterised the streams with permanent flow conditions. Furthermore, the amount of niche space filled by taxa in assemblages was significantly reduced in lowland intermittent watercourses, suggesting that these ecosystems are threatened by drought. Since benthic diatoms are important autotrophic elements of streams, any negative changes in their structure and composition may have a harmful eff ect on other assemblages, up to an ecosystem-level. Thus, lowland intermittent streams in continental regions require special attention for future eff ective biodiversity conservation.

\section{Acknowledgements}

The authors are thankful for the kind support of the Hungarian Academy of Sciences 'Lendület' Program. The authors were supported by the NKFIH K 119225 (PT, VB-B) and KH 129483 (PT) grants, and by the National Research, and Development and Innovation Office (GINOP-2.3.2-15-2016-00019) during manuscript preparation. AA was supported by the National Research, Development and Innovation Office (grant no.: PD 124681). TK was supported by the Premium Postdoctoral Research Program (grant no.: PPD2018-026/2018). Emmeline Topp (Georg-August-Universität Göttingen) kindly improved the English of the manuscript.

\section{Supplementary material}

Supplementary material associated with this article can be found, in the online version, at doi:10.1016/j.advwatres.2019.02.010.

\section{References}

Abonyi, A., Leitao, M., Lancon, A.M., Padisák, J., 2012. Phytoplankton functional groups as indicators of human impacts along the River Loire (France). Hydrobiologia 698, 233-249. https://doi.org/10.1007/s10750-012-1130-0.

Acuna, V., Datry, T., Marshall, J., Barceló, D., Dahm, C.N., Ginebreda, A., Mcgregor, G., Sabater, S., Tockner, K., Palmer, M.A., 2014. Why should we care about temporary waterways? Science 343, 1080-1081. http://dx.doi.org/10.1126/science.1246666.

Acuna, V., Casellas, M., Corcoll, N., Timoner, X., Sabater, S., 2015. Increasing extent of periods of no flow in intermittent waterways promotes heterotrophy. Freshwater Biol. 60, 1810-1823. https://doi.org/10.1111/fwb.12612.

Acuna, V., Hunter, M., Ruhi, A., 2017. Managing temporary streams and rivers as unique rather than second-class ecosystems. Biol. Conserv. 211, 12-19. https://doi.org/10.1016/j.biocon.2016.12.025.

Babka, B., Futó, I., Szabó, Sz, 2018. Seasonal evaporation cycle in oxbow lakes formed along the Tisza River in Hungary for flood control. Hydrol. Process. 32, 2009-2019. https://doi.org/10.1002/hyp.13126.

Barthès, A., Leflaive, J., Coulon, S., Peres, F., Rols, J.L., Ten-Hage, L., 2015. Impact of drought on diatom communities and the consequences for the use of diatom index values in the River Maureillas (Pyrénées-Orientales, France). River Res. Appl. 31, 9931002. https://doi.org/10.1002/rra.2793.

Bartholy, J., Pongracz, R., 2005. Tendencies of extreme climate indices based on daily precipitation in the Carpathian Basin for the 20th century. Q. J. Hung. Meteorol Serv. $109,1-20$

Bartholy, J., Pongracz, R., Pieczka, I., 2014. How the climate will change in this century? Hung. Geogr. Bull. 63, 55-67. https://doi.org/10.15201/hungeobull.63.1.5.

B-Béres, V., Török, P., Kókai, Zs., T-Krasznai, E., Tóthmérész, B., Bácsi, I., 2014. Ecological diatom guilds are useful but not sensitive enough as indicators of extremely changing water regimes. Hydrobiologia 738, 191-204. https://doi.org/10.1007/s10750-014-1929-y.

B-Béres, V., Lukács, Á., Török, P., Kókai, Zs., Novák, Z., T-Krasznai, E., Tóthmérész, B., Bácsi, I., 2016. Combined eco-morphological functional groups are reliable indicators of colonization processes of benthic diatom assemblages in a lowland stream. Ecol. Indic. 64, 31-38. https://doi.org/10.1016/j.ecolind.2015.12.031.

B-Béres, V., Török, P., Kókai, Zs., Lukács, Á., T-Krasznai, E., Tóthmérész, B., Bácsi, I., 2017. Ecological background of diatom functional groups: comparability of classification systems. Ecol. Indic. 82, 183-188. https://doi.org/10.1016/j.ecolind.2017.07.007.

Belda, M., Holtanova, E., Halenka, T., Kalvova, J., 2014. Climate classification revisited: from Köppen to Trewartha. Climate Res. 52, 1-13. https://doi.org/10.3354/cr01204.

Berger, W.H., Parker, F.L., 1970. Diversity of Planktonic Foraminifera in Deep-Sea Sediments. Science 3937, 1345-1347. https://doi.org/10.1126/science.168.3937.1345.

Berthon, V., Bouchez, Á., Rimet, F., 2011. Using diatom life forms and ecological guilds to assess organic pollution and trophic level in rivers: a case study of rivers in southeastern France. Hydrobiologia 673, 259-271. https://doi.org/10.1007/s10750-011-0786-1.
Bolgovics, Á., Ács, É., Várbíró, G., Kiss, K.T., Lukács, B.A., Borics, G., 2015. Diatom composition of the rheoplankton in a rhithral river system. Acta Botanica Croatica 74 (2), 303-316. https://doi.org/10.1515/botcro-2015-0028.

Bolgovics, Á., Várbíró, G., Ács, É., Trábert, Z., Kiss, K.T., Pozderka, V., Görgényi, J., Boda, P., Lukács, B.A., Nagy-László, Z., Abonyi, A., 2017. Phytoplankton of rhithral rivers: its origin, diversity and possible use for quality-assessment. Ecol. Indic. 81, 587-596. https://doi.org/10.1016/j.ecolind.2017.04.052.

Borics, G., Várbíró, G., Padisák, J., 2013. Disturbance and stress: different meanings in ecological dynamics? Hydrobiologia 711, 1-7. https://doi.org/10.1007/s10750-013-1478-9.

Cooper, S.D., Lake, P.S., Sabater, S., Melack, J.M., Sabo, J.L., 2013. The eff ects of land use changes on streams and rivers in mediterranean climates. Hydrobiologia 719, 383425. https://doi.org/10.1007/s10750-012-1333-4.

Datry, T., Larned, S.T., Fritz, K.M., Bogan, M.T., Wood, P.J., Meyer, E.I., Santos, A.N., 2014. Broad-scale patterns of invertebrate richness and community compositionin temporary rivers: eff ects of flow intermittence. Ecography 37, 94-104. https://doi.org/10.1111/j.1600-0587.2013.00287.x.

EN 13946 Water quality. Guidance standard for the routine sampling and pretreatment of benthic diatoms from rivers.

EN 14407 Water quality. Guidance standard for the identification, enumeration and interpretation of benthic diatom samples from running waters.

Falasco, E., Piano, E., Bona, F., 2016. Diatom flora in Mediterranean streams: flow intermittency threatens endangered species. Biodivers. Conserv. 25, 2965-2986. https://doi.org/10.1007/s10531-016-1213-8.

Hammer, Ø., Harper, D.A.T., Ryan, P.D., 2001. PAST: paleontological statistics software package for education and data analysis. Palaeontologia Electronica 4 (1), 9.

Hoff man, G., Werum, M., Lange-Bertalot, H., 2011. Diatomeen Im Süßwasser - Benthos Von Mitteleuropa.: Bestimmungsflora Kieselalgen Für Die ökologische Praxis. Über 700 Der Häufigsten Arten Und Ihre Ökologie. A.R.G. Gantner Verlag K.G., Ruggell.

IPCC Intergovernmental Panel on Climate Change. Climate Change 2014. Mitigation of Climate Change. Summary for policy makers and technical summary Available at: (accessed 10.05.2018)

ISO 15923-1:2013 Water quality - Determination determination of selected parameters by discrete analysis systems - Part part 1: Ammonium, nitrate, nitrite, chloride, orthophosphate, sulfate and silicate with photometric detection. pp. 12.

Kastovsky, J., Hauer, T., Mares, J., Krautova, M., Besta, T., Komarek, J., Desortova, B., Hetesa, J., Hindakova, A., Houk, V., Janecek, E., Kopp, R., Marvan, P., Pumann, P., Skácelova, O., Zapomelova, E., 2010. A review of the alien and expansive species of freshwater cyanobacteria and algae in the Czech Republic. Biol. Invasions 12, 35993625. https://doi.org/10.1007/s10530-010-9754-3.

Kókai, Zs., Bácsi, I., Török, P., Buczkó, K., T-Krasznai, E., Balogh, Cs., Tóthmérész, B., B-Béres, V., 2015. Halophilic diatom taxa are sensitively indicating even the short term changes in lowland lotic systems. Acta Botanica Croatica 74, 287-302. https://doi.org/10.1515/botcro-2015-0025.

Krammer, K., Lange-Bertalot, H., 1997a. Bacillariophyceae 1. naviculaceae. In: Gerloff , H., Heynig, J.H., Mollenhauer, D. (Eds.), Süsswasserflora Von Mitteleuropa. Elsevier, Heidelberg.

Krammer, K., Lange-Bertalot, H., 1997b. Bacillariophyceae 2., bacillariaceae, epithemiaceae, surirellaceae. In: Gerloff , H., Heynig, J.H., Mollenhauer, D. (Eds.), Süsswasserflora Von Mitteleuropa. Elsevier, Heidelberg.

Krammer, K., Lange-Bertalot, H., 2004a. Bacillariophyceae 3., centrales, fragilariaceae, eunotiaceae. In: Gerloff , H., Heynig, J.H., Mollenhauer, D. (Eds.), Süsswasserflora Von Mitteleuropa. Spektrum Akademischer Verlag, Heidelberg.

Krammer, K., Lange-Bertalot, H., 2004b. Bacillariophyceae 4., achnanthaceae. kritische erganzungen zu achnanthes s. l., navicula s. str., gomphonema. gesamtliteraturverzeichnis teil 1-4. In: Gerloff , H., Heynig, J.H., Mollenhauer, D. (Eds.), Süsswasserflora Von Mitteleuropa. Spektrum Akademischer Verlag, Heidelberg.

Laliberté, E., Legendre, P., 2010. A distance-based framework for measuring functional diversity from multiple traits. Ecology 91, 299-305. https://doi.org/10.1890/08-2244.1.

Laliberté, E., Legendre, P., Shipley, B., 2014. FD: Measuring Functional Diversity from Multiple traits, and Other Tools for Functional Ecology. R package Version 1.0-12. R Foundation for Statistical Computing, Vienna, Austria https://CRAN.R-project.org/package=FD.

Leibold, M.A., Chase, J.M., 2018. Metacommunity Ecology, 59. Princeton University Press.

Mason, N.W.H., Mouillot, D., Lee, W.G., Wilson, J.B., 2005. Functional richness, functional evenness and functional divergence: the primary components of functional diversity. Oikos 111, 112-118. https://doi.org/10.1111/j.0030-1299.2005.13886.x.

Meehl, G.A., Karl, T., Easterling, D.R., Changnon, S., Pielke, R., Changnon, D., Evans, J., Groisman, P.Y., Knutson, T.R., Kunkel, K.E., Mearns, L.O., Parmesan, C., Pulwarty, R., Root, T., Sylves, R.T., Whnetton, P., Zwiers, F., 2000. An introduction to trends in extreme weather and climate events: observations, socioeconomic impacts, terrestrial ecological impacts, and model projections. Bull. Am. Meteorol. Soc. 81, 413-416. https://doi.org/10.1175/1520-0477(2000)081<0413:AITTIE>2.3.CO;2.

MSZ EN 1899-1:2000 Water quality. Determination of biochemical oxygen demand after n days (BODn). pp. 17.

MSZ ISO 6060:1991 Water quality. Determination of the chemical oxygen demand pp. 6 . Novais, M.H., Morais, M.M., Rosado, J., Dias, L.S., Hoff mann, L., Ector, L., 2014. Diatoms of temporary and permanent watercourses in Southern Europe (Portugal). River Res. Appl. 30, 1216-1232. https://doi.org/10.1002/rra.2818.

Passy, S.I., 2007. Diatom ecological guilds display distinct and predictable behavior along nutrient and disturbance gradients in running waters. Aquatic Bot. 86, 171-178. https://doi.org/10.1016/j.aquabot.2006.09.018.

Passy, S.I., Larson, C.A., 2011. Succession in stream biofilms is an environmentallydriven gradient of stress tolerance. Microb. Ecol. 62, 414-424. https://doi.org/10.1007/s00248-011-9879-7. 
Piano, E., Falasco, E., Bona, F., 2017. How does water scarcity aff ect spatial and temporal patterns of diatom community assemblages in Mediterranean streams? Freshwater Biol. 62, 1276-1287. https://doi.org/10.1111/fwb.12944.

Potapova, M., Hamilton, P.B., 2007. Morphological and ecological variation within the Achnanthidium minutissimum (Bacillariophyceae) species complex. J. Phycol. 43, 561-575. https://doi.org/10.1111/j.1529-8817.2007.00332.x.

Rimet, F., Bouchez, Á., 2012. Life-forms, cell sizes and ecological guilds of diatoms in European rivers. Knowl. Manage. Aquatic Ecosyst. 406, 1283-1299. https://doi.org/10.1051/kmae/2012018.

Rimet, F., Gomà, J., Cambra, J., Bertuzzi, E., Cantonati, M., Cappelletti, C., Ciutti, F., Cordonier, A., Coste, M., Delmas, F., Tison, J., Tudesque, L., Vidal, H., Ector, L., 2007. Benthic diatoms in western European streams with altitudes above $800 \mathrm{~m}$ : characterisation of the main assemblages and correspondence with ecoregions. Diatom Res. 22, 147-188. https://doi.org/10.1080/0269249X.2007.9705702.

Rosett, V., Ruhi, A., Bogan, M.T., Datry, T., 2017. Do lentic and lotic communities respond similarly to drying? Ecosphere 8 (7), e01809. https://doi.org/10.1002/ecs2.1809.

Rothrock, M.J., Garcia-Pichel, F., 2005. Microbial diversity of benthic mats along a tidal desiccation gradient. Environ. Microbiol. 7, 593-601. https://doi.org/10.1111/j.1462-2920.2005.00728.x.

Skoulikidis, N.T., Sabater, S., Datry, T., Morais, M.M., Buff agni, A., Dörflinger, G., Zogaris, S., Sánchez-Montoya, M.M., Bonada, N., Kalogianni, E., Rosado, J., Vardakas, L., de Girolamo, A.M., Tockner, K., 2017. Non-perennial Mediterranean rivers in Europe: status, pressures, and challenges for research and management. Sci. Total Environ. 577, 1-18. https://doi.org/10.1016/j.scitotenv.2016.10.147.

Stenger-Kovács, Cs., Körmendi, K., Lengyel, E., Abonyi, A., Hajnal, É., Szabó, B., Buczkó, K., Padisák, J., 2018. Expanding the trait-based concept of benthic diatoms: development of trait- and species-based indices for conductivity as the master variable of ecological status in continental saline lakes. Ecol. Indic. 95, 63-74. https://doi.org/10.1016/j.ecolind.2018.07.026.

Stenger-Kovács, Cs., Lengyel, E., 2015. Taxonomical and distribution guide of diatoms in soda pans of Central Europe. Studia Botanica Hungarica 46, 3-203. https://doi.org/10.17110/StudBot.2015.46.Suppl.3.

Stenger-Kovács, Cs., Lengyel, E., Crossetti, L.O., Üveges, V., Padisák, J., 2013. Diatom ecological guilds as indicators of temporally changing stressors and disturbances in the small Torna-stream, Hungary. Ecol. Indic. 24, 138-147. https://doi.org/10.1016/j.ecolind.2012.06.003.

Steward, A.L., von Schiller, D., Tockner, K., Marshall, J.C., Bunn, S.E., 2012. When the river runs dry: human and ecological values of dry riverbeds. Front. Ecol. Environ. 10, 202-209. https://doi.org/10.1890/110136.

Stubbington, R., England, J., Sefton, C., Wood, P.J., 2017. Temporary streams in temperate zones: recognizing, monitoring and restoring transitional aquatic-terrestrial ecosystems. Wiley Interdiscip. Rev. 4, e1223. https://doi.org/10.1002/wat2.1223.

Stubbington, R., Chadd, R., Cid, N., Csabai, Z., Milisa, M., Morais, M., Munne, A., Paril, P., Pesic, V., Tziortzis, I., Verdonschot, R.C.M., Datry, T., 2018. Biomonitoring of intermittent rivers and ephemeral streams in Europe: current practice and priorities to enhance ecological status assessments. Sci. Total Environ. 618, 1096-1113. https://doi.org/10.1016/j.scitotenv.2017.09.137.

Stubbington, R., Paillex, A., England, A., Barthès, A., Bouchez, A., Rimet, F., SánchezMontoya, M., Westwood, C.G., Datry, T.A., 2019. Comparison of biotic groups as dryphase indicators of ecological quality in intermittent rivers and ephemeral streams. Ecol. Indic. 97, 165-174. https://doi.org/10.1016/j.ecolind.2018.09.061.

ter Braak, C.J.F., Smilauer, P., 2002. CANOCO Reference Manual and CanoDraw for Windows User's Guide: Software for Canonical Community Ordination (Version 4.5). Microcomputer Power, Ithaca, NY (Accessed. 2013) http://www.canoco.com .

Tölle, M.H., Schefczyk, L., Gutjahr, O., 2017. Scale dependency of regional climate modeling of current and future climate extremes in Germany. Theor. Appl. Climatol. 1-20. https://doi.org/10.1007/s00704-017-2303-6.

Tornes, E., Ruhi, A., 2013. Flow intermittency decreases nestedness and specialisation of diatom communities in Mediterranean rivers. Freshwater Biol. 58, 2555-2566. https://doi.org/10.1111/fwb.12232.

van Dam, H., Mertens, A., Sinkeldam, J., 1994. A coded checklist and ecological indicator values of freshwater diatoms from The Netherlands. Neth. J. Aquatic Ecol. 28, 117133. https://doi.org/10.1007/BF02334251.

Ziemann, H., Kies, L., Schulz, C., 2001. Desalinization of running waters III. Changes in the structure of diatom assemblages caused by a decreasing salt load and changing ion spectra in the River Wipper (Thuringia, Germany). Limnologica 31, 257-280. https://doi.org/10.1016/S0075-9511(01)80029-3. 